\title{
PENGELOLAAN KEUANGAN MASJID DI JABODETABEK
}

\author{
Rini Rini \\ Universitas Islam Negeri Syarif Hidayatullah Jakarta \\ Email: rini@uinjkt.ac.id \\ DOI: https://doi.org/10.5281/jakis.v6i2.112
}

\begin{abstract}
The purpose of this research is to describe the financial management of mosques in Jabodetabek (Jakarta, Bogor, Tangerang and Bekasi). Financial management in terms of the preparation of financial statements, types of financial statements made, media publication of financial statement, bank accounts owned by mosques, types of sources of mosque fund receipts and audits of mosque financial statements. This research uses quota sampling. There are 185 districts in the Jabodetabek area, and the sample of mosques from 40 sub-districts is determined. Samples were taken randomly as many as 3 mosques per district. Data sources come from interviews with mosque finance managers. Number of sample in this research is 116 mosques. The results showed that most of the mosques already had financial statements. The types of financial statements that are made mostly are only cash reports. Publication of financial statement to worshipers, mostly by announcing at Friday prayers. The account owned by the mosque is mostly in the name of the manager. Mosque reception mainly comes from infaq and waqf of pilgrims. Only a small number of mosques have been audited for their financial statements.
\end{abstract}

Keywords: Nonprofit organization, financial management of mosque, financial statement of mosque.

\section{PENDAHULUAN}

Dalam agama Islam terdapat prinsip yang menyatakan bahwa manusia adalah khalifah di bumi (QS 6:165; 57:7). Sebagai khalifah, manusia harus menunaikan kewajiban dan memelihara amanah (QS 4:58; 23:8 dan 70:32), karena amanah ini nantinya akan dipertanggungjawabkan (QS 75:36; 17:36).

Urusan agama dan ekonomi saling berhubungan bagi seorang muslim. Akuntansi melebihi daripada hanya sebuah aktivitas teknikal, ia merupakan aktivitas socio-technical dan Islam berperan penting dalam membentuk praktik akuntansi (Baydoun, et.al, 2018). Akuntansi dapat membangun suatu model yang sesuai dengan kebutuhan masjid sehingga informasi yang dihasilkan dapat meningkatkan kualitas entitas masjid yang dapat menggerakkan aktivitas masjid. Informasi keuangan yang dihasilkan oleh praktik akuntansi di masjid, dapat menjadi bagian dari pada peningkatan kualitas ummah dan bertransformasi untuk kepentingan masyarakat.

Masjid merupakan salah satu organisasi nirlaba (Nordiawan, 2006). Sebagai sebuah organisasi nirlaba, tentunya masjid mengelola dana yang diterima dari pemerintah, perusahaan dan donatur (masyarakat). Organisasi nirlaba memperoleh sumberdaya dari sumbangan para penyumbang yang 
tidak mengharapkan imbalan, pembayaran kembali atau pengembalian manfaat ekonomi yang sebanding dengan jumlah sumberdaya yang diberikan (Nordiawan, 2006; Ikatan Akuntan Indonesia, 2011; Rini, 2016). Pada organisasi nirlaba ini akuntabilitas dan transparansi adalah merupakan isu yang sangat penting (Scala, 1992; Clark \& Sare, 2000). Salah satu media untuk mewujudkan akuntabilitas dan transparansi ini adalah laporan keuangan (Rini, 2016).

Sesuai dengan Pernyataan Standar Akuntansi Keuangan (PSAK) 45 tahun 2011 tentang Pelaporan Keuangan Entitas Nirlaba, bahwa organisasi nirlaba membuat laporan keuangan dan melaporkannya kepada para pemakai laporan. Masjid sebagai organisasi nirlaba (Nordiawan, 2006), seharusnya membuat laporan keuangan yang terdiri dari laporan posisi keuangan, laporan aktivitas dan laporan arus kas serta catatan atas laporan keuangan.

Beberapa ahli sudah meneliti peran akuntansi dalam konteks religius (khususnya gereja) yang memandang adanya pemisahan urusan dunia akhirat (Laughlin, 1988, 1990; Booth, 1993; Jacoobs, 2005). Hal ini sangat berbeda dengan prinsip Islam, dimana Islam adalah agama yang komprehensif dan universal (Antonio, 1999), sehingga dalam Islam tidak ada pemisahan aspek dunia (secular/profane) aspek akhirat (sacred). Dampaknya, Islam mewarnai praktik akuntansi (Baydoun, et.al, 2018)

Namun, disadari masih kurangnya literatur mengenai praktik akuntansi di organisasi nirlaba, termasuk lembaga keagamaan (Booth, 1993; Carmona \& Ezzamel, 2006). Begitupun dengan praktik akuntansi di masjid, belum banyak yang membahasnya (Shaharuddin dan Sulaiman, 2015). Padahal masjid merupakan entitas pelaporanakuntansiyangmenggunakan dana masyarakat sebagai sumber keuangannya, dalam bentuk sumbangan, sedekah atau bentuk bantuan sosial lainnya yang berasal dari masyarakat (publik). Karena itu, sebagai bagian dari entitas publik, masjid mempertanggungjawabkan semua aktivitasnya kepada publik. Transparansi dan akuntabilitas menjadi kata kunci yang penting bagi entitas publik untuk bertahan dan memaksimalkan perannya pada domain sosial budaya dimana entitas tersebut berada yang berbeda dengan entitas publik lainnya (Simajuntak, D.A dan Januarsi, 2011). Apalagi, masjid memiliki potensi dana surplus yang sangat besar apabila dikelola dengan baik (Haq dan Dewi, 2013).

Pengurus masjid yang merupakan bagian dari khalifah secara personal bertanggung jawab atas sumber daya yang diamanahkan kepadanya secara langsung ataupun melalui organisasi mereka (Baydoun, et.al, 2018). Dalam Islam, manusia (pengurus masjid) harus bertanggung jawab secara vertical dan horizontal (Harahap, 2001, 2007; Adnan, 2005). Terdapat dua akuntabilitas yang mesti diwujudkan pengurus masjid, yaitu akuntabilitas vertikal (pertanggungjawaban kepada Allah) dan akuntabilitas horizontal (pertanggungjawaban kepada jamaah atau masyarakat). Dengan pelaporan keuangan yang berkualitas dapat diwujudkan kedua akuntabilitas tersebut (Adnan, 2005; Badu dan Hambali, 2014). 
Sumber dana masjid berasal dari zakat, wakaf, infak, sedekah, sumbangan, bantuan, dan sebagainya (Ayub, Muhsin \& Mardjoned, 1996 dalam Haq dan Dewi, 2013). Biasanya pengelolaan sumber dana yang terdapat di masjid dilakukan oleh ta'mir dan bendahara masjid. Namun menurut Khanan (2010) ta'mir masjid sebagai pengelola kurang mengetahui persis gambaran pengalokasian dana.

Alim dan Abdullah (2010) mengungkapkan terdapat beberapa faktor yang terkait dengan sistem pengendalian manajemen dimasjid, yaitu kurangnya akuntabilitas dalam mengelola sistem akuntansi, kurangnya partisipasi anggaran dimasjid dan ketidaktepatan dalam pencatatan dan pelaporan, dan cara efektif dalam mencari sumber pendapatan masjid. Penelitian lain yang berhubungan dengan pengelolaan laporan keuangan adalah studi kasus yang dilakukan oleh Andarsari (2015) dalam pembuatan laporan keuangan masjid. Adnan (2013) juga mengungkapkan praktik pengelolaan keuangan telah diterapkan oleh manajemen masjid yang ada di Yogyakarta meskipun pengetahuan dan kemampuan manajemen masjid masih harus ditingkatkan lagi. Shaharuddin dan Sulaiman (2015) mengungkapkan Masjid qaryah di Kuala Terengganu telah menyiapkan dan mengungkapkan laporan keuangannya kepada anggota qaryah (jamaah dan donatur). Penelitian ini menunjukan adanya kepuasan dari praktik pengungkapan tersebut. Yunita Fitria (2017) yang melakukan riset di 3 Masjid di Kalimantan Timur, menemukan bahwa mekanisme yang dilakukan oleh ketiga masjid yang ada di Kalimantan timur cenderung menggunakan akuntabilitas informal, karena penyampaian laporan keuangan masjid umumnya melalui pengumuman takmir masjid pada saat pelaksanaan sholat Jum'at.

Badu dan Hambali (2014) melakukan penelitian di sejumlah masjid di Gorontalo. Ia menemukan masih rendahnya pelaporan keuangan masjid di Gorontalo dan belum banyak pengurus yang sadar akan pentingnya pelaporan keuangan masjid dalam mewujudkan akuntabilitas keuangan. Badu dan Hambali (2014) menyatakan terdapat tiga hal yang menyebabkan masih rendahnya masjid yang melaporkan keuangannya. Pertama, minimnya pemahaman masyarakat tentang pentingnya pelaporan keuangan. Kedua, masih terbatasnya perhatian pemerintah terhadap organisasi masjid. Ketiga, sumber daya yang belum mumpuni dalam mengelola keuangan.

Berdasarkan uraian di atas, maka perlu diadakan penelitian mengenai pengelolaan keuangan masjid di wilayah Jabodetabek. Jabodetabek adalah wilayah yang meliputi Kota Jakarta (Jakarta Utara-Barat-Pusat-TimurSelatan), Kota \& Kabupaten Bogor, Kota Depok, Kota \& Kabupaten Tangerang serta Kota \& Kabupaten Bekasi. Alasan menggunakan wilayah Jabodetabek karena sebagai wilayah metropolitan yang berada di pusat pemerintahan, Jabodetabek mempunyai kekuatan ekonomi, kekuatan inovasi dan teknologi dan kualitas urban (Baskara, 2009). 


\section{TELAAH TEORITIS}

\subsection{AKUNTANSI SEKTOR PUBLIK}

Terdapat beberapa bidang akuntansi. Ada akuntansi keuangan, akuntansi manajemen, akuntansi biaya, akuntansi sektor publik, pemeriksaan akuntansi, akuntansi Islam dan lain sebagainya (Baydoun, et.al, 2018). Secara sederhana, akuntansi terdiri atas dua yaitu akuntansi untuk bisnis dan akuntansi organisasi nirlaba. Dalam organisasi nirlaba dibagi lagi dalam dua kelompok entitas yaitu entitas pemerintahan dan entitas nirlaba non pemerintahan (Bastian, 2007).

Secara umum, yang membedakan secara signifikan antara organisasi sektor publik dengan perusahaan (Nordiawan, 2006):

1. Tujuan organisasi

Perusahaan bertujuan untuk memaksimalkan kesejahteraan pemegang saham melalui penciptaan keuntungan, sedangkan organisasi sektor publik mempunyai tujuan untuk meningkatkan kesejahteraan masyarakat melalui pelayanan.

2. Sumber pendanaan

Perusahaan didanai melalui hasil operasi perusahaan bersangkutan, selain investasi dari pemegang saham. Sementara sesuai dengan tujuan, organisasi sektor publik mendanai operasinya tidak melalui laba operasi, tetapi melalui cara khusus berupa sumbangan atau donasi yang bersifat secara sukarela.

3. Peraturan perundangan

Organisasi sektor publik khususnya lembaga pemerintah harus melakukan aktivitas sesuai peraturan perundang-undangan. Bagi perusahaan bisa memilih aktivitas mana yang akan dilakukan atau produk apa yang dibuat berdasarkan pertimbangan untung atau rugi.

Masjid merupakan organisasi nirlaba yang harus dikelola keuangannya dengan baik dan mengikuti ketentuan sesuai Pernyataan Standar Akuntansi Keuangan No. 45 mengenai Akuntansi Entitas Nirlaba. Belum ada peraturan pemerintah yang mengharuskan pengurus masjid untuk melaksanakan PSAK tersebut. Penerapan PSAK 45 masih bersifat sukarela. Dan belum ada peraturan yang membahas penggunaan dana yang diperoleh masjid.

\subsection{AKUNTANSI DAN AGAMA}

Triyuwono (2000) berpendapat bahwa akuntansi dibentuk oleh lingkungannya melalui interaksi sosial yang kompleks (complicated social interaction). Selanjutnya ia juga mengatakan, walaupun pandangan tradisional melihat bahwa akuntansi dibangun melalui interaksi sosial (social constructed) sebagai hasil dari kejadian sosial, ekonomi, dan politik, namun 
ada pendekatan lain yang melihat bahwa akuntansi dapat membentuk lingkungannya dengan interaksi sosial (socially constructing). Ini membuktikan bahwa akuntansi bukanlah suatu bentuk ilmu pengetahuan dan praktik yang bebas nilai (value free), tetapi sebaliknya akuntansi adalah disiplin dan praktik dan sangat sarat dengan nilai.

Akuntansi dibentuk oleh lingkungannya (Morgan, 1988; Hines, 1989; dan Francis, 1990), namun kemudian, akuntansi juga mempengaruhi lingkungannya (Mathews dan Perera, 1993). Sehingga akuntansi memiliki dua arah, yaitu dipengaruhi dan mempengaruhi (Triyuwono, 2015).

Jacob (2004) mengutip Eliade (1959) mengungkapkan bagi seseorang yang sangat religius maka semua sudut pandangnya akan sesuatu selalu didasari oleh pemahaman spiritual, oleh karena itu maka praktek akuntansinya pun akan dipenuhi dengan dimensi spiritual, sebaliknya bagi seseorang yang tidak religius maka persepsinya adalah akuntansi merupakan ilmu bebas dari pengaruh dimensi spiritual. Pendapat Eliade tersebut sejalan dengan Baydoun, et.al (2018) yang mengatakan bagi Muslim, ajaran Islam akan mempengaruhi aktivitas kehidupannya termasuk praktik akuntansi. Namun beberapa ilmuwan ada juga yang berpendapat akuntansi merupakan bagian dari ilmu dan praktik keduniawian yang terpisah dari kehidupan maupun nilai keagamaan atau spiritual (Laughlin, 1988, 1990; Booth, 1993). Eliade (1959) menemukan bahwa persepsi entitas keagamaan seperti Gereja didominasi oleh pemahaman bahwa akuntansi adalah praktik yang domain kerjanya hanya pada praktik keuangan yang berkarakteristik duniawi, sehingga entitas keagamaan menganggap disiplin ilmu ini tidak banyak dibutuhkan dalam kerja-kerja pelayanan di lembaga keagamaan.

\subsection{PRAKTIK AKUNTANSI DI LEMBAGA AGAMA}

Riset yang membahas mengenai hubungan antara akuntansi dan agama atau institusi agama masih sedikit (Carmona dan Ezzamel, 2006). Booth (1993) menguraikan tiga hal utama yang dibahas dalam literatur mengenai praktik akuntansi di lembaga agama (gereja), adalah:

1. Kurang memadainya praktik akuntansi, seperti: lemahnya pengendalian intern, sistem akuntansi yang kuno dan tidak memadai, kurangnya tenaga ahli dan komitmen untuk pengelolaan keuangan.

2. Adanya gambaran bahwa baiknya praktik akuntansi di gereja yang kontras dengan buruknya mayoritas praktik akuntansi.

3. Perspektif lain yang menyatakan adanya perbedaan antara aspek spritual dan non spritual, sekuler dan non sekuler yang mempengaruhi dalam merancang dan mengimplementasikan sistem akuntansi.

Praktik akuntansi di gereja sudah diteliti oleh Laughlin (1988, 1990); Booth (1993); dan Jacobs (2004, 2005). Beberapa riset lain tentang praktik akuntansi di gereja barat sebagaimana diungkapkan oleh Shaharuddin dan Sulaiman (2015), telah dilakukan oleh Woodbine, 1997; Duncan et al. 1999; 
Duncan and Flesher 2002; Parker 2002; Wooten et al. 2003; Bowrin 2004; Elso et al. 2007; and Ventura and Daniel 2010.

Studi mengenai praktik akuntansi di kuil Mesir Kuno dilakukan oleh Ezzamel (2002, 2005). Sedangkan Fonfeder, Holtzman dan Maccarrone (2003) meneliti praktik akuntansi di kuil Yerussalem kuno (Carmona dan Ezzamel, 2006).

Beberapa peneliti akuntansi Islam juga sudah melakukan riset praktik akuntansi di Masjid. Di Indonesia dan Malaysia telah banyak meriset praktik akuntansi masjid, diantaranya (Shaharuddin dan Sulaiman, 2015); (Simajuntak, D.A dan Januarsi, 2011); (Haq dan Dewi, 2013); Alim dan Abdullah (2010); Andarsari (2015); Adnan (2013); Fitria (2017); Badu dan Hambali (2014); Wahab (2008); Said, et.al (2013); dan Adil et.al (2013).

\subsection{AKUNTABILITAS PUBLIK}

Akuntabilitas publik adalah kewajiban penerima tanggung jawab untuk mengelola sumber daya, melaporkan, dan mengungkapkan segala aktivitas dan kegiatan yang berkaitan dengan penggunaan sumber daya publik kepada pihak pemberi mandat (principal). Akuntabilitas berbeda dengan konsep responsibilitas (Mahmudi, 2005: 9). Akuntabilitas dapat dilihat sebagai salah satu elemen dalam responsibiltas.

Akuntabilitas juga berarti kewajiban untuk rnempertanggungjawabkan apa yang telah dilakukan atau tidak dilakukan oleh seseorang. Sedangkan responsibilitas merupakan akuntabilitas yang berkaitan dengan kewajiban menjelaskan kepada orang/pihak lain yang memilikikewenangan untuk meminta pertanggungjawaban dan memberi penilaian. Namun demikian, tuntutan akuntabilitas harus diikuti dengan pemberian kapasitas untuk melakukan keleluasaan dan kewenangan.

Akuntabilitas publik terdiri dari akuntabilitas vertikal dan akuntabilitas horisontal. Akuntabilitas vertikal merupakan akuntabilitas kepada otoritas yang lebih tinggi, sedangkan akuntabilitas horizontal adalah akuntabilitas kepada publik secara luas atau terhadap sesama lembaga lannya yang tidak memiliki hubungan atasan bawahan.

Menurut Shahul (2000) mekanisme dari akuntabilitas terdiri dari:

1. Pengungkapan dan pelaporan keuangan

2. Penilaian kinerja dan evaluasi

3. Partisipasi

4. Perbaikan peraturan

5. Pengauditan sosial

Akuntabilitas keuangan masjid berbentuk:

a. Akuntabilitas horizontal

Pertanggungjawaban pengelolaan masjid kepada jamaah dan masyarakat sekitar 
b. Akuntabilitas vertikal

Pertanggungjawaban pengelolaan masjid kepada Allah SWT.

\section{METODE PENELITIAN}

Penelitian ini merupakan penelitian deskriptif kualitatif. Sumber data berasal dari wawancara dengan pengurus masjid. Wawancara dilakukan untuk mengetahui pengelolaan keuangan masjid di Jabodetabek. Dipilihnya wilayah Jabodetabek karena merupakan wilayah metropolitan yang terdiri dari Jakarta, Bogor (Kota dan Kabupaten), Depok dan Tangerang (Kota dan Kabupaten). Variasi daerah di Jabodetabek mewakili Indonesia.

Pengambilan sampel memakai kuota dan dilakukan secara acak. Dari 185 kecamatan yang ada di Jabodetabek, ditetapkan kuota untuk sampel sebanyak 40 kecamatan. Pada tabel 1 ditampilkan data jumlah kecamatan dan kuotanya di masing-masing wilayah Jabodetabek.

Tabel 1. Data Jumlah kecamatan dan kuota Sampel

\begin{tabular}{clcc}
\hline No & \multicolumn{1}{c}{ Nama Wilayah } & Jumlah Kecamatan & Kuota Kecamatan \\
\hline 1 & Kab. Adm. Kep.Seribu & 2 & - \\
\hline 2 & Kota Jakarta Utara & 6 & 1 \\
\hline 3 & Kota Jakarta Pusat & 8 & 1 \\
\hline 4 & Kota Jakarta Barat & 8 & 1 \\
\hline 5 & Kota Jakarta Timur & 10 & 3 \\
\hline 6 & Kota Jakarta Selatan & 10 & 2 \\
\hline 7 & Kab. Bogor & 40 & 9 \\
\hline 8 & Kota Bogor & 6 & 1 \\
\hline 9 & Kota Depok & 11 & 3 \\
\hline 10 & Kab. Bekasi & 23 & 2 \\
\hline 11 & Kota Bekasi & 12 & 2 \\
\hline 12 & Kab. Tangerang & 19 & 5 \\
\hline 13 & Kota Tangerang & 13 & 7 \\
\hline 14 & Kota Tangerang Selatan & 17 & 40 \\
\hline Jumlah & 185 & \\
\hline
\end{tabular}

Jumlah Masjid yang akan dijadikan sampel sebanyak 3 masjid per kecamatan, yang dipilih secara acak dan terdiri dari masjid berukuran besar, menengah dan kecil. Diharapkan akan terkumpul data dari 40 kecamatan dengan masing-masing 3 masjid, sehingga jumlah keseluruhan sebanyak 120 masjid. Wawancara dilakukan pada hari Sabtu dan Minggu, dengan mempertimbangkan kesibukan sebagian pengurus masjid yang bekerja di 
kantor. Sebanyak 20 mahasiswa diterjunkan ke masjid yang berada di 40 kecamatan diatas. Masing-masing mahasiswa melakukan wawancara ke 6 masjid. Sehingga diharapkan terkumpul data dari 120 masjid.

Instrumen wawancara disusun dengan mengacu pada penelitian Adnan (2015) dan PSAK 45. Adapun pertanyaan yang diajukan dalam wawancara adalah sebagai berikut:
a. Adanya laporan keuangan dan jenis laporan keuangan yang dibuat
b. Publikasi laporan keuangan
c. Rekening bank yang dimiliki masjid
d. Sumber-sumber penerimaan masjid
e. Adanya audit laporan keuangan

\section{HASIL DAN PEMBAHASAN}

Dalam riset ini direncanakan wawancara ke pengurus masjid di 40 kecamatan dengan masing-masing 3 masjid, sehingga diharapkan diperoleh data dari 120 masjid. Wawancara dilaksanakan pada hari Sabtu dan Minggu pada tanggal 13 dan 14 November 2015, dengan pertimbangan kemungkinan sebagian pengurus juga bekerja di kantor. Namun pada akhirnya hanya terkumpul data dari 116 masjid sebagaimana dijabarkan pada tabel 2 .

Tabel 2. Data sampel penelitian

\begin{tabular}{clccl}
\hline No & $\begin{array}{l}\text { Nama } \\
\text { Wilayah }\end{array}$ & $\begin{array}{c}\text { Jumlah } \\
\text { Kecamatan }\end{array}$ & $\begin{array}{l}\text { Jumlah } \\
\text { Masjid }\end{array}$ & Nama Kecamatan \\
\hline 1 & $\begin{array}{l}\text { Kota Jakarta } \\
\text { Utara }\end{array}$ & 1 & 2 & Kemayoran \\
\hline 2 & $\begin{array}{l}\text { Kota Jakarta } \\
\text { Pusat }\end{array}$ & 1 & 1 & Senen \\
\hline 3 & $\begin{array}{l}\text { Kota Jakarta } \\
\text { Barat }\end{array}$ & 1 & 3 & Kebon Jeruk \\
\hline 4 & $\begin{array}{l}\text { Kota Jakarta } \\
\text { Timur }\end{array}$ & 3 & 8 & $\begin{array}{l}\text { Ciracas, Pasar Rebo, } \\
\text { Kramat Jati }\end{array}$ \\
\hline 5 & $\begin{array}{l}\text { Kota Jakarta } \\
\text { Selatan }\end{array}$ & 2 & 9 & $\begin{array}{l}\text { Pasar Minggu, Cilandak, } \\
\text { Pesanggrahan }\end{array}$ \\
\hline 6 & Kab. Bogor & 9 & 24 & $\begin{array}{l}\text { Parung Panjang, Ciawi, } \\
\text { Cisarua, Parung, Bojong } \\
\text { Gede, Cileungsi, } \\
\text { Gunung Putri, } \\
\text { Cibungbulang, } \\
\text { Leuwiliang }\end{array}$ \\
& & 1 & 3 & $\begin{array}{l}\text { Bogor Tengah } \\
\text { Cinere, Limo, } \\
\text { Cimanggis }\end{array}$ \\
\hline 7 & Kota Bogor & 3 & 9 & \begin{tabular}{l} 
Kota Depok \\
\hline 8
\end{tabular} \\
\hline
\end{tabular}




\begin{tabular}{clccl}
\hline 9 & Kab. Bekasi & 2 & 6 & $\begin{array}{l}\text { Tambun Selatan, } \\
\text { Cibitung }\end{array}$ \\
\hline 10 & Kota Bekasi & 2 & 6 & Jati Asih, Bekasi Barat \\
\hline 11 & $\begin{array}{l}\text { Kab. } \\
\text { Tangerang }\end{array}$ & 5 & 15 & $\begin{array}{l}\text { Teluk Naga, Pasar } \\
\text { Kemis, Tigaraksa, } \\
\text { Kelapa Dua, Cisauk }\end{array}$ \\
\hline 12 & $\begin{array}{l}\text { Kota } \\
\text { Tangerang }\end{array}$ & 7 & 21 & $\begin{array}{l}\text { Batu Ceper, Larangan, } \\
\text { Karang Tengah, } \\
\text { Cipondoh, Kalideres, } \\
\text { Karawaci, Ciledug. }\end{array}$ \\
\hline 13 & $\begin{array}{l}\text { Kota } \\
\text { Tangerang } \\
\text { Selatan }\end{array}$ & 3 & 9 & $\begin{array}{l}\text { Setu, Serpong, Serpong } \\
\text { Utara }\end{array}$ \\
\hline Jumlah & 40 & 116 & \\
\hline
\end{tabular}

Beberapa pengurus tidak bisa diwawancara karena: Pertama, sebagian pengurus masjid di Jabodetabek liburan keluar kota. Wawancara yang dilakukan pada hari Sabtu dan Minggu juga berdampak sebagian pengurus tidak bisa ditemui karena liburan bersama keluarganya ke luar kota. Kedua, adanya kekhawatiran sebagian pengurus masjid data keuangan masjid ini diberikan ke KPK atau pihak terkait lainnya. Untuk itu kami meyakinkan kalau data akan dijaga kerahasiaannya, dan penelitian hanya untuk melihat pengelolaan keuangan masjid, tidak meminta data keuangan secara detil.

Wawancara dilakukan sebanyak dua kali. Wawancara pertama dengan menemui langsung pengurus masjid di lokasi masjidnya. Wawancara kedua dilaksanakan sewaktu mengadakan pelatihan pengelolaan keuangan masjid di UIN Jakarta.

Berikut ini ditampilkan rekapitulasi hasil wawancara dengan pengurus masjid mengenai pengelolaan keuangan.

Tabel 3. Hasil Wawancara Pengelolaan Keuangan Masjid

\begin{tabular}{rrrcc}
\hline No. & \multicolumn{1}{c}{ Pernyataan } & Total & $\%$ \\
\hline 1 & Apakah Masjid mempunyai laporan keuangan? & 113 & $97.41 \%$ \\
\hline 2 & Apa laporan keuangan yang dimiliki masjid? & & \\
\hline & a. & Laporan penerimaan dan pengeluaran kas & 114 & $98.28 \%$ \\
\hline b. & Neraca (laporan posisi keuangan) & 32 & $27.59 \%$ \\
\hline c. & Laporan penerimaan \& pengeluaran dana kurban & 101 & $87.07 \%$ \\
\hline d. & Laporan nama pihak yang berkurban & 104 & $89.66 \%$ \\
\hline e. & Laporan nama pihak yang menerima kurban & 86 & $74.14 \%$ \\
\hline f. & Laporan penerimaan \& pengeluaran zakat & 107 & $92.24 \%$ \\
\hline g. & Laporan nama pemberi zakat & 102 & $87.93 \%$ \\
\hline h. & Laporan nama penerima zakat & 93 & $80.17 \%$ \\
\hline
\end{tabular}




\begin{tabular}{|c|c|c|c|}
\hline & $\begin{array}{l}\text { Laporan penerimaan \& pengeluaran dana infak, } \\
\text { sedekah dan wakaf }\end{array}$ & 101 & $87.07 \%$ \\
\hline & j. Laporan nama pemberi infak, sedekah \& wakaf & 89 & $76.72 \%$ \\
\hline & k. Laporan nama penerima infak, sedekah dan & 83 & $71.55 \%$ \\
\hline & 1. Rincian Aset Tetap & 39 & $33.62 \%$ \\
\hline & m. Laporan pembayaran gaji pengelola masjid & 83 & $71.55 \%$ \\
\hline & n. Laporan pembayaran honor pengurus masjid & 59 & $50.86 \%$ \\
\hline & $\begin{array}{ll}\text { Laporan aktivitas (Penerimaan \& Pengeluaran } \\
\text { perProgram) }\end{array}$ & 89 & $76.72 \%$ \\
\hline & p. Kwitansi Pengeluaran Kas Kecil ke Pengelola & 71 & $61.21 \%$ \\
\hline & q. Kwitansi Honor Penceramah & 30 & $25.86 \%$ \\
\hline & r. $\quad$ Berita Acara Penghitungan Kotak Infak & 81 & $69.83 \%$ \\
\hline & h. Laporan Keuangan bulanan & 83 & $71.55 \%$ \\
\hline & i. Laporan keuangan tahunan & 70 & $60.34 \%$ \\
\hline 3 & $\begin{array}{l}\text { Apakah laporan keuangan masjid dipublikasikan pada } \\
\text { jamaah? }\end{array}$ & 76 & $65.52 \%$ \\
\hline & a. Ditulis secara detil di papan tulis masjid & 44 & $37.93 \%$ \\
\hline & b. Ditempel di papan pengumuman & 67 & $57.76 \%$ \\
\hline & c. Difotocopy dan dibagikan ke jamaah & 14 & $12.07 \%$ \\
\hline & d. Laporan keuangan dan lainnya dibukukan & 68 & $58.62 \%$ \\
\hline \multirow[t]{2}{*}{4} & Apakah masjid mempunyai rekening bank? & 69 & $59.48 \%$ \\
\hline & $\begin{array}{l}\text { Jika ya sebutkan Atas nama siapa? Bank } \\
\text { syariah/konvensional? }\end{array}$ & 69 & $59.48 \%$ \\
\hline \multirow[t]{5}{*}{5} & Apa saja sumber penerimaan masjid & & \\
\hline & a. Infak, Sedekah dan Wakaf via kotak amal & 116 & $100.00 \%$ \\
\hline & b. Infak, Sedekah dan Wakaf via transfer bank & 46 & $39.66 \%$ \\
\hline & c. Sewa & 20 & $17.24 \%$ \\
\hline & d. Usaha lainnya (sebutkan)............... & 24 & $20.69 \%$ \\
\hline 6 & Apakah laporan keuangan masjid sudah diaudit? & 12 & $10.34 \%$ \\
\hline 7 & $\begin{array}{l}\text { Bersediakah mengikuti pelatihan "Optimalisasi } \\
\text { Pengelolaan Keuangan Masjid" ? Jika tidak, Jelaskan } \\
\text { alasan........................... }\end{array}$ & 67 & $57.76 \%$ \\
\hline
\end{tabular}


Sebanyak 97.41\% masjid mempunyai laporan keuangan. Ketika dikonfirmasi ulang pada saat FGD yang dimaksud dengan laporan keuangan bagi sebagian besar pengurus adalah laporan kas. Padahal disadari masjid juga mempunyai aset-aset lain, yang belum dibuat pelaporannya dengan sistematis.Sejumlah $98.28 \%$ masjid mempunyai laporan penerimaan dan pengeluaran kas. Karena bagi mereka yang penting adalah pertanggungjawaban kas (penerimaan dan pengeluaran kas).Hanya $27.59 \%$ masjid di Jabodetabek yang menyusun laporan keuangan. Ini menunjukkan masih belum terwujudnya akuntabilitas keuangan masjid di Jabodetabek. Akuntabilitas keuangan dapat diwujudkan dengan adanya pelaporan keuangan yang sesuai standar akuntansi.

Untuk kegiatan kurban, sebanyak $87.07 \%$ masjid yang membuat laporan penerimaan dan pengeluaran dana qurban. Untuk laporan nama pihak yang berkurban dibuat oleh $89.66 \%$, sedangkan untuk laporan nama pihak yang menerima kurban, hanya sebanyak $74.14 \%$ masjid yang melaporkannya. Seharusnya masjid juga membuat daftar nama penerima kurban, agar bisa dievaluasi dan dibandingkan dengan masjid lainnya, sehingga kurban yang diberikan pada orang yang tepat serta terjaminnya pembagian kurban yang merata (tidak ada warga yang menerima banyak daging kurban, sedangkan yang lain tidak mendapat bagian sama sekali).

Jumlah masjid yang membuat laporan penerimaan dan pengeluaran dana zakat sebanyak 92.24\%. Sedangkan laporan yang terpisah mengenai rincian laporan nama pemberi zakat, sebanyak $87.93 \%$ masjid melaporkannya, dan hanya $80,17 \%$ yang membuat laporan rincian penerima zakat.Sebanyak $87.07 \%$ masjid membuat laporan penerimaan dan pengeluaran dana infak, sedekah dan wakaf. Sedangkan untuk laporan nama pemberi infak, sedekah dan wakaf hanya dilaporkan sebanyak $76.72 \%$ dan laporan nama penerima infak, sedekah dan wakaf dibuat oleh $71.55 \%$ masjid.

Untuk daftar rincian aktiva tetap, sangat kurang kesadaran masjid untuk mencatatnya. Hanya $33.62 \%$ masjid yang mencatat secara rinci aktiva tetap yang mereka miliki. Hal ini berpotensi menimbulkan kehilangan aset masjid.Laporan pembayaran gaji pengelola masjid dibuat oleh $71.55 \%$ masjid.Untuk laporan pembayaran honor pengurus masjid, hanya dibuat oleh sebanyak 50.86\%. Ini disebabkan tidak banyak masjid yang membayar gaji pengurusnya. Sebagian besar pengurus bekerja tidak digaji dan mungkin juga karena sebagian masjid ini masih kecil pendapatannya, hanya cukup untuk operasional masjid. Dan sebagian pengeluaran terkadang dibayar oleh pengurus secara pribadi.

Untuk laporan aktivitas per program yang dilakukan masjid, sebanyak $76.72 \%$ masjid membuatnya.Hanya $61.21 \%$ masjid yang membuat kwitansi pengeluaran kas kecil ke pengelola. Padahal untuk kas mesti kuat pengendaliannya.Sangat sedikit masjid yang membuat kwitansi honor penceramah, yaitu sebanyak $25.86 \%$. Sedangkan hal ini sangat rentan untuk disalahgunakan. Bisa saja yang dicatat sebagai honor berbeda dengan yang diterima oleh penceramah.Berita acara penghitungan kotak infak, dibuat oleh 
$69.83 \%$ masjid.Laporan keuangan bulanan sebanyak $71.55 \%$ masjid membuatnya, namun untuk laporan keuangan tahunan lebih sedikit yang membuatnya, yaitu sebanyak $60.34 \%$.

Untuk publikasi laporan keuangan masjid, sebanyak $65.52 \%$ masjid mempublikasikannya. Namun ketika ditanyakan lebih lanjut sarana untuk publikasikan, 1) ditulis di papan tulis masjid sebanyak $37.93 \%$; 2) ditempel di papan pengumuman $57.76 \%, 3$ ) difotocopy dan dibagikan ke jamaah hanya sebanyak $12.07 \%$, 4) dibukukan sebanyak 58.62\%.Dari paparan ini terlihat masih rendah kesadaran pengurus untuk publikasi laporan keuangan. Umumnya mereka melaporkan hanya secara lisan, setiap hari Jum'at atau pada bulan ramadhan, saat tarawih. Padahal dengan publikasi akan terwujud transparansi dan akuntabilitas pelaporan keuangan masjid yang lebih baik.

Hanya sebanyak $59.48 \%$ masjid mempunyai rekening bank. Umumnya kas masjid tergabung ke rekening pribadi bendahara masjid. Kemungkinan hal ini terjadi karena kas masjid belum terlalu banyak dan sebagian besar masjid belum mempunyai variasi sumber pendanaan juga. Sebagian kecil masjid sudah mempunyai rekening bank syariah.

Untuk sumber penerimaan, $100 \%$ berasal dari infak, sedekah dan wakaf melalui kotak amal. Hanya $39.66 \%$ masjid yang infak, sedekah dan wakaf melalui transfer bank. Sebanyak $17.24 \%$ masjid menyewakan sebagian ruangannya dan memperoleh pendapatan dari usaha sewa ini. Dan sebanyak 20.69\% mempunyai usaha lain seperti parkir, kebun, dan lainnya. Sangat sedikit sekali masjid yang sudah diaudit laporan keuangannya.

Dari 116 masjid yang diwawancarai, hanya 12 masjid atau $10.34 \%$ yang sudah diaudit. Hal ini memang bisa terjadi karena dari paparan diatas baru sedikit yang membuat laporan keuangan secara lengkap. Dan untuk audit pun membutuhkan biaya yang besar, bagi sebagian masjid pengeluaran tersebut lebih baik untuk keperluan lain.Dari wawancara dengan pengurus masjid ketika ditanyakan kesediaan untuk mengikuti pelatihan "optimalisasi pengelolaan keuangan masjid", hanya $65.52 \%$ yang bersedia. Sebagian besar alasan tdk bersedia karena pelatihan diadakan di hari kerja, sedangkan sebagian pengurus merupakan karyawan.

Tujuan penelitian ini adalah mengetahui pengelolaan keuangan masjid di Jabodetabek. Dalam penelitian mengenai pengelolaan keuangan masjid ini ada lima hal utama yang diteliti, yaitu pertama, adanya penyusunan laporan keuangan dan jenis laporan keuangan yang dibuat; kedua, media publikasi laporan keuangan; ketiga, rekening bank yang dimiliki masjid; keempat, sumber-sumber penerimaan masjid; dan kelima, Adanya audit laporan keuangan.

Pertama, berdasarkan wawancara semua masjid di Jabodetabek sudah membuat laporan keuangan. Namun terdapat kesalahan persepsi dari pengurus masjid mengenai laporan keuangan ini. Dalam pandangan pengurus masjid, laporan keuangan yang harus mereka buat hanyalah laporan penerimaan dan pengeluaran kas. Temuan ini sejalan Simajuntak dan Januarsi (2011). Padahal menurut PSAK 45 tahun 2011, laporan keuangan entitas nirlaba meliputi laporan posisi keuangan, laporan aktivitas, laporan 
arus kas dan catatan atas laporan keuangan. Terlepas dari kesalahan persepsi mengenai laporan keuangan dibandingnya dengan PSAK 45, setidaknya sebagai bagian dari entitas publik, masjid di Jabodetabek sudah mempertanggungjawabkan semua aspek keuangannya kepada masyarakat, khususnya jamaah masjid. Pertanggungjawaban keuangan ini dilakukan karena sumber keuangan masjid dari sumbangan, sedekah atau bentuk bantuan sosial lainnya yang berasal dari masyarakat (publik) (Simajuntak dan Januarsi, 2011; Haq dan Dewi, 2013; Ikatan Akuntan Indonesia, 2011; Rini, 2016).

Dari temuan riset terlihat masih sangat sedikitnya masjid yang membuat laporan keuangan secara lengkap. Banyaknya masjid yang masih belum melakukan pelaporan keuangan secara memadai, karena:

1) Kurangnya kesadaran untuk membuat pelaporan keuangan masjid

2) Pencatatan masih dalam bentuk single entry bukan dalam bentuk double entry.

3) Kurangnya sumber daya untuk membuat laporan keuangan yang sesuai standar akuntansi ini.

4) Belum adanya pedoman akuntansi masjid, menyebabkan pengurus masjid kurang yakin dalam menyusun laporan keuangan.

5) Catatan keuangan yang merupakan pertanggungjawaban keuangan masjid belum disampaikan dan dikomunikasikan kepada masyarakat umum sebagai pihak yang berhubungan langsung dengan kegiatan masjid.

Kendala pelaporan keuangan ini mendukung temuan Booth (1993), Badu dan Hambali (2014), dan beberapa penelitian menyatakan hal yang senada. Kendala yang sama dari tahun 1990an sampai sekarang, memperlihatkan masih kurangnya perhatian kalangan pendidik akuntansi untuk memperbaiki kelemahan masyarakat ini. Padahal seharusnya pendidikan mampu mengatasi masalah-masalah yang ada di masyarakat.

Kedua, media publikasi laporan keuangan mayoritas dilakukan secara informal. Penyampaian informasi keuangan masjid kepada jamaah sebagian besar hanya pada saat pelaksanaan ibadah sholat Jum'at dan ditempel di papan pengumuman masjid. Padahal dengan kedua cara ini kontinuitas data untuk menilai kinerja masjid agak sulit, karena hanya diketahui hari tersebut atau maksimal sebulan ditempel pengumuman tersebut. Sedikit sekali masjid yang memfotokopikan dan membagikan laporan keuangan ini pada jamaah masjid. Ini mendukung temuan Fitria (2017) yang menyatakan akuntabilitas keuangan masjid bersifat informal. Padahal di era teknologi informasi ini sebaiknya masjid di Jabodetabek dapat memberikan informasi keuangan yang luas kepada masyarakat khususnya jamaah dan bisa dilakukan secara murah melalui internet (Rini, 2016). Hal ini perlu menjadi perhatian pengurus masjid karena penyampaian informasi keuangan masjid akan meningkatkan kepuasan jamaah (Shaharuddin dan Sulaiman, 2015) dan sebagai perwujudan akuntabilitas vertikal kepada Allah SWT dan akuntabilitas horizontal kepada jamaah (Hameed, 2000; Harahap, 2001, 2007; Adnan 2005, 2013). 
Ketiga, mayoritas rekening bank yang dimiliki masjid masih atas nama pengurus masjid. Adanya rekening atas nama masjid itu sendiri, mengharuskan dibentuknya entitas masjid berupa yayasan. Sebagian besar masjid belum berbentuk yayasan, karena belum tercapainya kesepakatan antar jamaah masjid. Rekening yang belum atas nama masjid berpotensi menimbulkan masalah keuangan ketika pergantian pengurus. Pengurus baru harus membuat rekening baru lagi, sehingga besar kemungkinan adanya beberapa catatan keuangan yang tidak terlihat kontinuitasnya. Selain itu sebagian besar rekening masjid di Jabodetabek juga di bank konvensional. Seharusnya sebagai institusi keagamaan Islam, masjid membuka rekening di bank syariah, supaya aktivitasnya lebih berkah dan mendukung perkembangan bank syariah di Indonesia.

Keempat, sumber penerimaan masjid adalah infak, sedekah dan wakaf baik dari jamaah maupun pihak lainnya yang bersifat tidak mengikat. Temuan ini sejalan dengan Simajuntak dan Januarsi (2011), Haq dan Dewi (2013), Badu dan Hambali (2014).

Kelima, masih sangat sedikit masjid yang sudah melakukan audit laporan keuangan. Ini sejalan dengan masih sedikitnya masjid yang mempunyai laporan keuangan lengkap. Faktor lainnya karena biaya audit membutuhkan biaya besar, sedangkan pengurus dan jamaah masjid berpendapat lebih baik dana audit tersebut digunakan untuk operasional dan pengembangan masjid, maupun untuk keperluan sosial jamaah lainnya.

Karena berbagai temuan lapangan sebagaimana dijelaskan diatas, sebaiknya kalangan pendidik akuntansi khususnya akuntansi Islam secara proaktif di masa yang akan datang mengusahakan untuk membuat pelatihan mengenai manajemen masjid modern khususnya pengendalian intern, pengelolaan keuangan masjid dan penyusunan laporan keuangan masjid dan publikasi laporan keuangan masjid dan kegiatan atau program masjid melalui internet.

Untuk pelatihan kemungkinan juga ada beberapa masalah yang belum diketahui sehingga antusias peserta kurang. Dari wawancara di lapangan untuk meningkatkan pengelolaan keuangan masjid, UIN Jakarta mengundang pengurus masjid untuk mengikuti pelatihan dan sebanyak 67 dari 116 masjid bersedia hadir. Namun hanya 21 masjid yang menghadiri pelatihan pertama mengenai pengelolaan keuangan masjid secara global. Dan pada pelatihan kedua mengenai penyusunan laporan keuangan masjid hanya 14 masjid yang menghadirinya. Untuk itu, di masa yang akan datang akan lebih efektif untuk pelatihan dan pendampingan langsung diadakan di beberapa masjid yang akan dibina.

\section{SIMPULAN}

Pengurus masjid berpendapat masjid sudah mempunyai laporan keuangan. Namun hanya sebagian kecil masjid yang mempunyai laporan keuangan sesuai PSAK. Jenis laporan keuangan yang dibuat sebagian besar hanya 
laporan kas. Publikasi laporan keuangan kepada jamaah, mayoritas dengan cara mengumumkan pada saat sholat Jum'at dan ditempel pada papan pengumumanp. Rekening yang dimiliki masjid sebagian besar atas nama pengurus. Penerimaan masjid terutama berasal dari infak dan wakaf jamaah. Hanya sebagian kecil masjid yang sudah diaudit laporan keuangannya.

Untuk mengatasi problem yang ada dalam pengelolaan keuangan masjid, sebaiknya di masa yang akan kalangan pendidik akuntansi khususnya akuntansi Islam secara proaktif di masa yang akan datang mengusahakan untuk membuat pelatihan mengenai manajemen masjid modern khususnya pengendalian intern, pengelolaan keuangan masjid dan penyusunan laporan keuangan masjid dan publikasi laporan keuangan masjid dan kegiatan atau program masjid melalui internet. Pelatihan dan pendampingan sebaiknya dilaksanakan di sejumlah kecil masjid, supaya lebih efektif.

\section{DAFTAR PUSTAKA}

Adnan, M.A. (2005). Akuntansi Syariah: Arah Prospek dan Tantangannya. Yogyakarta: UII Press.

Adil, M.A.M, Sanusi, Z.M., Jaafar, N. A. Khalid, M. M \& Aziz, A. A. (2013). "Financial Management Practices of Mosques in Malaysia". GJAT, 3 (1)

Adnan, M.A. (2013). "The Financial Management Practices of the Mosques in the Special Region of Yogyakarta Province, Indonesia". Tazkia Islamic Finance and Business Review, 8(2).

Alim, A. P., Abdullah, S. R. (2010). “Audit Pengurusan Masjid : Kajian di Daerah Pasir Puteh, Kelantan”. Universiti Teknologi Malaysia Institutional Repository, 1-7

Andarsari, P. R. (2016). "Laporan Keuangan Organisasi Nirlaba (Lembaga Masjid)". Universitas Kediri. Jurnal Ekonika Volume, 1(2)

Badu, R. S \& Hambali, I. R. (2014). Studi Ethnoscience: Dilema Transparansi dan Akuntansi dalam Pelaporan Sumbangan Donatur dan Pengelolaan Keuangan Masjid (Studi Kasus di Kabupaten Gorontalo). Laporan Penelitian. Universitas Negeri Gorontalo.

Baydoun, N., Sulaiman, M., Willet, R.J., Ibrahim, S.H. (2018). Principle of Islamic Accounting. Singapore: Wiley

Booth, P. (1993). Accounting in Churches: A Research Framework and Agenda. Accounting, Auditing \& Accountability Journal, 6(4), 37-67.

Carmona, S., \& Ezzamel, M. (2006). Accounting and religion: A historical perspective. Accounting History, 11(2), 117-127. http://doi.org/10.1177/1032373206063109 
Clark, C \& Sare, J. (2000). Transparency Means Greater Accountability for Non Profits. Trusts \& Estates; Sep 2000; 139, 9, pg.17-18.

Fitria, Y. 2017. “Akuntabilitas pada Organisasi Religi; Studi Kasus MasjidMasjid di Balikpapan, Kalimantan Timur". AKUNTABEL 14(1)

Haq, J.A.A, \& Dewi, M.K. 2013. "Praktik Manajemen Keuangan Masjid dan Potensi Dana Masjid (Studi Kasus Pada Beberapa Masjid di Kota Bogor)". Universitas Indonesia.

Harahap, S. S. (2001). Mепијu Perumusan Teori Akuntansi Islam. Jakarta: Pustaka Quantum.

Harahap, S. S. (2007). Krisis Akuntansi Kapitalis \& Peluang Akuntansi Syariah. Jakarta: Pustaka Quantum

Ikatan Akuntan Indonesia. (2011). PSAK 45: Pelaporan Keuangan Entitas Nirlaba.

Jacobs, K. (2005). The sacred and the secular: Examining the role of accounting in the religious context. Accounting, Auditing and Accountability Journal, 18(2), 189-210. http://doi.org/10.1108/09513570510588724

Kamaruddin, M. I. H, dan Ramli, N.M. 2017. "A Case Study of Internal Control Practices in Islamic Non-Profi Organizations in Malaysia". Asian Journal of Accounting and Governance, 8, 13-25

Kewo, Cecilia Lelly. 2014. "The Effect of Participative Budgeting, Budget Goal Clarity and Internal Control Implementation on Managerial Performance". Research Journal of Finance and Accounting, 5(12)

Laughlin, R. (1988). Accounting in its social context: An analysis of the accounting systems of the Church of England. Accounting, Auditing \& Accountability Journal, 1(2), 19-42. http://doi.org/http://dx.doi.org/10.1108/EUM0000000004622

Laughlin, R. C. (1990), 'A model of Financial Accountability and the Church of England,' Financial Accountability and Management, 6 (2), 93114.

Mardiasmo. (2009). Akuntansi Sektor Publik. Yogyakarta: Andi.

Masrek, M. N, Mohammed, I.S, Daud, N. M, Arshad, R \& Omar. (2014). "Internal Financial Controls Practices of District Mosques in Central Region of Malaysia.". International Journal of Trade, Economics and Finance, 5, 255-258

Morgan, G. G., \& Morgan, G. G. (2011). New development : Churches and charity accounting (December 2014), 37-41. http://doi.org/10.1080/09540960903378175 
Nahar, H.S, and Hisham Yaacob. 2011. "Accountability in the sacred context: The case of management, accounting, reporting of a Malaysian cash awqaf institution." Journal of Islamic Accounting and Business Research 2 (2): 87-113.

Nordiawan, D. (2006). Akuntansi Sektor Publik. Jakarta: Salemba Empat

Rini, R. (2016). Penerapan Internet Financial Reporting untuk Meningkatkan Akuntabilitas Organisasi Pengelola Zakat. Jurnal Akuntansi Multiparadigma, $\quad 7(2), \quad 288-306$. http://doi.org/http://dx.doi.org/10.18202/jamal.2016.08.7022

Scala, R. (1992). Foundations Grapple with Ethics, Scandals, Accountability. Fund Raising Management; 23(5), 47-50.

Said, J., Mohamed, A., Sanusi, Z. M. \& Yusuf, S. N. S. (2013). "Financial Management Practices in Religious Organizations: An Empirical Evidence of Mosque in Malaysia". International Business Research; $6(7)$

Sanusi, M.Z., Johari, R.J, Said, J., Iskandar, T. (2015). “The Effects of Internal Control System, Financial Management and Accountability of NPOs: The Perspective of Mosques in Malaysia". Procedia Economics and Finance, 28, 156-162

Sekaran, Uma.Bougie, Roger. (2016). Research Methods for Business. 6th Edition. UK: John Wiley \& Sons.

Shaharuddin, Shahida, dan Maliah Sulaiman. (2015). "Financial Disclosure and Budgetary Practices of Religious Organization: A Study of Qaryah Mosques in Kuala Terengganu”. Gadjah Mada International Journal of Business, 17(1) (January-April 2015): 83-101

Shahul Hameed (2000), The need for accounting; Perceptions of its objectives and characteristics by Malaysian Accountants and Academics, PhD Thesis. University of Dundee

Simajuntak, D.A dan Januarsi, Y. (2011). Akuntabilitas dan Pengelolaan Keuangan Masjid. Proceeding. Simposium Nasional Akuntansi XIV, Aceh.

Siraj, S. A., Ibrahim, S. H. M., and Sulaiman, M. (2007), "The Financial Management Practices of State Mosques in Peninsular Malaysia". Indonesian Management \& Accounting Research. 6 (2), 65-86.

Sulaiman, M., Siraj, S. A. and Ibrahim, S. H. M. (2008). "Internal control systems in West Malaysia's State Mosques". American Journal of Islamic Social Sciences, 25 (1), 63.

Triyuwono, Iwan. (2000). Organisasi dan Akuntansi Syariah. LKiS. Yogyakarta. 
Triyuwono, I. (2015). Akuntansi Syariah: Perspektif, Metodologi dan Teori. Jakarta: Rajawali Pers

Wahab, A. A. (2008). "Financial Management of Mosques in Kota Setar District: Issues and Challenges". College of Business Universiti Utara Malaysia

Yasmin, S., Haniffa, R. \& Hudaib, M. (2014). "Communicated Accountability by Faith-Based Charity Organisations." Journal of Business Ethics, 122: 103-123. 